\title{
The Relationship Between Writing Anxiety and Writing Self-Efficacy of Students Learning Turkish as a Foreign Language
}

\author{
Ahmet BAŞKAN ${ }^{1}$ \\ ${ }^{1}$ Hitit University, Turkish Teaching Application and Research Center, Çorum, Turkey \\ Correspondence: Ahmet BAŞKAN, Hitit University Turkish Teaching Application and Research Center, Çorum. \\ Turkey. E-mail: ahmetbaskanturkce@gmail.com
}

Received: April 30, $2021 \quad$ Accepted: May 31, $2021 \quad$ Online Published: June 7, 2021
doi:10.5539/jel.v10n4p70
URL: https://doi.org/10.5539/jel.v10n4p70

\begin{abstract}
The study aimed to determine the relationship between writing anxiety and writing self-efficacy of students learning Turkish as a foreign language. The study sample consisted of 247 international students at B1 and B2 levels at the Turkish Education Application and Research Center of a foundation university. The Writing Anxiety Scale for Learners of Turkish as a Foreign Language, developed by Şen and Boylu (2017), was used to determine students' writing anxiety. There were 13 items and two factors on the scale: Action-Oriented Anxiety and Environmental Oriented Anxiety. The Writing Self-Efficacy Scale for Turkish Students who Learn Turkish was developed by Büyükikiz (2012) to determine the students' writing self-efficacy. This two-factor scale had 16 items and explained $56.85 \%$ of the variance. The research was designed based on the relational screening model. SPSS 21.0 package programs were used to analyze the data. The study results indicated a significant positive relationship between writing anxiety and writing self-efficacy of students who learned Turkish as a foreign language. Besides, there was no significant difference between the Turkish learners' scores from the writing anxiety scale and their language level.
\end{abstract}

Keywords: writing skill, writing anxiety, writing self-efficacy, Turkish as a foreign language

\section{Introduction}

Writing is the correct and elaborate communication of feelings, thoughts, wishes, and events within specific rules and symbols (Özbay, 2011, p. 5). Considering the process and stages of acquiring writing skills, it can be inferred that acquiring writing skills in a foreign language is a longer and more complicated process than acquiring writing skills in the native language (Boylu, 2014, p. 338). Several affective factors, such as self-efficacy and anxiety, are influential in the acquisition of writing skills.

Self-efficacy, which is defined as the "situational awareness of a person about their capacity to perform a specific action successfully" (Bandura, 1982), is one of the most critical factors in the acquisition and development of writing skills. One's self-efficacy beliefs play a role in the amount of effort on specific tasks, the perseverance in solving problems, and coping and recovery skills against adverse situations. Self-efficacy beliefs also affect the amount of anxiety and stress when individuals are involved in an activity. A higher sense of self-efficacy indicates greater effort, persistence, and flexibility. In other words, self-efficacy beliefs substantially determine the achievements (Pajares \& Miller, 1994; Wood \& Bandura, 1989, p. 366; Demir, 2014, p. 28).

The concept of self-efficacy originates in the social-cognitive theory developed by Albert Bandura and the principle of reciprocal determinism, one of the critical components of the theory. The principle of reciprocal determination refers to personal factors, behaviors, and environmental conditions affecting each other and determining subsequent behavior. Accordingly, self-efficacy can be defined as one's beliefs about their capacity to produce specific performance attainments (Bandura, 2010). Self-efficacy belief signals the self-confidence in a field and is closely associated with the desires to execute a task in that field and the strengths to overcome the emerging challenges (Y1lmaz Soylu \& Akkoyunlu, 2019, p. 2235).

Successful execution of a task makes a person believe that it would be executed successfully again. One's beliefs about their skills considerably determine what s/he can do (Kurt, 2012). In this sense, students with writing self-efficacy believe that they will succeed even before writing, and they can easily maintain the 
behavior thanks to high motivation (Demir, 2013, p. 92). Besides, students' self-efficacy beliefs also influence their learning and motivation (Özonat, 2015). Self-efficacy is the variable significantly predicting the writing performance, the use of writing strategies, and writing skills (Y1lmaz Soylu \& Akkoyunlu, 2019; Matoti \& Shumba, 2011; Hidi \& Boscolo, 2008).

Writing anxiety is the tension experienced before or during the writing. Many factors such as lack of knowledge and self-confidence, the fear of receiving negative criticism, and inadequacy are influential in writing anxiety. It also triggers certain behaviors such as avoidance of writing, reluctance to write, which damages writing skills and dispositions, and prevents the acquisition of writing habits. Concentration problem is one of the challenges closely related to anxiety that negatively affects the writing skill (Demir, 2016). Writing anxiety is a reaction against writing, which sometimes can be motivating or disturbing. Writing anxiety is closely associated with emotional symptoms such as sadness, anger, fear, and physical symptoms such as cramping and sweating (Petzel \& Wenzel, 1993). According to Thompson (1980), writing anxiety is a 'fear of the writing that outweighs the projected gain from the ability to write.' If the anxiety, as the source of motivation, is less or more than the desired level, a person experiences problem in writing. Pamuk et al. (2014) divide anxiety into state anxiety - temporary anxiety - and permanent anxiety. State anxiety occurs when a desire or need is not satisfied, and when they are satisfied, it disappears spontaneously. Permanent anxiety stems from a security need and its long-term unsatisfaction (Aşılığlu \& Özkan, 2013; İşeri \& Ünal, 2012).

There are many reasons for writing anxiety: insufficient knowledge about the subject matter and the spelling rules or fear of not being liked. Besides, the writing skill covers several fields such as vocabulary, grammar, phonetics, and semantics, which can trigger writing anxiety in students. Writing anxiously often leads to skipping the overall integrity of the text due to sticking to the details, the loss of authenticity in narration, and the incorrect and incomplete expression of thoughts (Karakuş Tayşi \& Taşkın, 2018, p. 1176). A lower or higher level of anxiety than the optimal level negatively affects academic achievement (Gardner, 1985; Ehrman \& Oxford, 1995; MacIntyre et al., 1997). In other words, it is reasonable to expect students to worry about a learning material. However, it should remain at a certain level. High or low anxiety negatively affects learning. The critical point is to keep the anxiety at a moderate level (Sevim \& Özdemir Erem, 2013, p. 976).

This study aimed to determine the relationship between writing anxiety and students' writing self-efficacy who learned Turkish as a foreign language. Accordingly, answers to the following questions were sought:

- What is the relationship between writing anxiety and writing self-efficacy of students who learn Turkish as a foreign language?

- Is there a significant relationship between the writing anxiety and self-efficacy of the students who learn Turkish as a foreign language by language level?

- Is there a significant relationship between the students' writing anxiety and writing self-efficacy who learn Turkish as a foreign language by gender?

\section{Method}

\subsection{Research Design}

The correlational (relational) survey model, one of the general survey model types, was preferred in the study. The relational survey model is used to determine the presence and degree of co-change between two or more variables (Fraenkel \& Wallen, 2009). A survey model aims to describe a past or present situation and define a subject, event, or object under its conditions (Karasar, 2009). The relational survey model, on the other hand, is "used to determine the relationships between two or more variables" (Büyüköztürk et al., 2014). The correlations between variables in relational survey models are examined in two ways: the type of correlation and comparison. The correlation type determines whether and how the variables co-change. There are at least two variables in the comparison type, and groups are formed by one variable (independent variable) and examined whether there is a change in terms of the other variable (dependent variable) (Karasar, 2009).

\subsection{Participants}

The sample included 247 international students at B1 and B2 levels who learned Turkish as a foreign language at the Turkish Education Application and Research Center of a university in Turkey. 
Table 1. Participants' language levels

\begin{tabular}{lll}
\hline Level & $\mathbf{N}$ & $\mathbf{\%}$ \\
\hline B1 & 151 & 59 \\
B2 & 91 & 35.5 \\
C1 & 14 & 5.5 \\
Total & $\mathbf{2 5 6}$ & $\mathbf{1 0 0}$ \\
\hline
\end{tabular}

As seen in Table 1, 151 participants were at the B1 level, 91 were at the B2 level, and 14 were at the $\mathrm{C} 1$ level.

Table 2. Information about the gender of the participants

\begin{tabular}{lll}
\hline Gender & $\mathbf{N}$ & $\mathbf{\%}$ \\
Female & 139 & 54.3 \\
Male & 117 & 45.7 \\
Total & $\mathbf{2 5 6}$ & $\mathbf{1 0 0}$ \\
\hline
\end{tabular}

As can be seen in the table above, 139 were female, and 117 were male.

\subsection{Data Collection Tools}

In the study, The Writing Anxiety Scale for Learners of Turkish as a Foreign Language, developed by Şen and Boylu (2017), was used to determine students' writing anxiety who learned Turkish as a foreign language. There were 13 items and two factors on the scale: action-oriented anxiety and environment-oriented anxiety. The Writing Self-Efficacy Scale for Turkish Students who Learn Turkish was developed by Büyükikiz (2012) to determine the students' writing self-efficacy. The scale had 16 items and explained $56.85 \%$ of the variance.

\subsection{Data Analysis}

The study data were analyzed using SPSS 21.0 package programs. A normality test was performed to examine whether the participants showed a normal distribution of writing anxiety and writing self-efficacy. The normality test results are presented in Table 3 below.

Table 3. Normality test results

\begin{tabular}{lllllll}
\hline & \multicolumn{2}{l}{ Kolmogorov-Smirnova } & \multicolumn{2}{l}{ Shapiro-Wilk } \\
\cline { 2 - 7 } & Statistic & df & P & Statistic & Df & P \\
\hline Writing Anxiety & .087 & 256 & .000 & .970 & 256 & .000 \\
Writing Self-Efficacy & .056 & 256 & .048 & .985 & 256 & .010 \\
\hline
\end{tabular}

Büyüköztürk et al. (2009) state that if the sample is more than 50, the Kolmogorov-Smirnova test should be performed, and if it is less than 50, the Shapiro-Wilk test should be preferred. Therefore, the data were analyzed considering the Kolmogorov-Smirnova test results since there were 50 participants in the study group. According to the Kolmogorov-Smirnova test results in Table 3, the data did have a normal range $(\mathrm{p}<0.05)$.

\section{Findings}

\subsection{Is There a Significant Relationship Between Writing Anxiety and the Self-Efficacy of Turkish Learners?}

The Spearman Correlation test results regarding the relationship between writing anxiety and writing self-efficacy are shown in Table 4 below.

Table 4. Spearman correlation test results

\begin{tabular}{lllll}
\hline & & Writing Anxiety & Writing Self-Efficacy \\
\hline Spearman's rho & Writing Anxiety & Correlation Coefficient & 1.000 & $.150^{*}$ \\
& & $\mathrm{P}$ &. & .016 \\
& $\mathrm{~N}$ & 256 & 256 \\
& \multirow{4}{*}{ Writing Self-Efficacy } & Correlation Coefficient & $.150^{*}$ & 1.000 \\
& & $\mathrm{P}$ & .016 &. \\
& $\mathrm{~N}$ & 256 & 256 \\
\hline
\end{tabular}


According to Ural and Kılıç (2013, p. 244), if the correlation coefficient is between $0-0.29$, the significance is weak; if it is between 0.30-0.64, it is medium; if it is between 0.65-0.84, it is strong, and if it is between 0.85-, it is powerful. As shown in Table 4, there was a weak and positively significant correlation between writing anxiety and writing self-efficacy.

\subsection{Is There a Significant Relationship Between Writing Anxiety and Self-Efficacy of Turkish Learners by} Language Level?

The results of the Kruskal-Wallis test aiming to determine whether there was a significant relationship between the writing anxiety and writing self-efficacy of Turkish learners their language level is shown in Table 5 below.

Table 5. Kruskal-Wallis H test results

\begin{tabular}{lllllll}
\hline & Level & $\mathrm{N}$ & Mean Rank & $\mathrm{Sd}$ & $\mathrm{X}^{2}$ & $\mathrm{P}$ \\
\hline Writing Anxiety & B1 & 151 & 134.40 & 2 & 3.55 & 0.170 \\
& B2 & 91 & 116.91 & & & \\
& C1 & 14 & 140.14 & & & \\
Writing Self-Efficacy & B1 & 151 & 118.93 & 2 & 7.42 & $0.024^{*}$ \\
& B2 & 91 & 139.08 & & & \\
& C1 & 14 & 162.96 & & & \\
\hline
\end{tabular}

As shown in Table 5, the Kruskal Wallis test results indicated no significant difference between the Turkish learners' scores from the writing anxiety scale and their language levels $(\mathrm{p}>0.05)$. However, there was a significant difference between the Turkish learners' scores from the writing self-efficacy scale and language level $(\mathrm{p}<0.05)$. The Post Hoc Games-Howell test results regarding the groups with a significant difference are presented in Table 6 below.

Table 6. The Post Hoc Games-Howell test results

\begin{tabular}{llllll}
\hline & Level (I) & Level (J) & Mean Difference (I-J) & SH & p \\
\hline Writing Anxiety & B1 & B2 & 1.441 & 0.920 & 0.263 \\
& & C1 & -0.592 & 1.572 & 0.925 \\
& B2 & B1 & -1.441 & 0.920 & 0.263 \\
& & C1 & -0.203 & 1.650 & 0.449 \\
Writing Self-Efficacy & C1 & B1 & 0.592 & 1.572 & 0.925 \\
& & B2 & 2.033 & 1.650 & 0.449 \\
& B1 & B2 & -3.491 & 2.177 & 0.247 \\
& B2 & C1 & -6.535 & 5.354 & 0.461 \\
& B1 & 3.491 & 2.177 & 0.247 \\
& C1 & C1 & -3.044 & 5.557 & 0.849 \\
& & B1 & 6.535 & 5.354 & 0.461 \\
\end{tabular}

According to Table 6, there was no statistically significant difference in the Post-Hoc Games-Howell test results to determine the significant difference between Turkish learners' writing self-efficacy perceptions and language levels.

\subsection{Is There a Significant Relationship Between Writing Anxiety and Self-Efficacy of Turkish Learners by Gender?}

The results of the Mann-Whitney $U$ test, which was performed to determine whether there was a significant relationship between the writing anxiety and writing self-efficacy of Turkish learners by gender, are presented in Table 7. 
Table 7. Mann-Whitney U test results by gender

\begin{tabular}{lllllll}
\hline & Gender & N & Mean Rank & Total Rank & U Value & p \\
\hline Writing Anxiety & Female & 139 & 128.45 & 17854.50 & 8124.50 & 0.99 \\
& Male & 117 & 128.56 & 15041.50 & & \\
Writing Self-Efficacy & Female & 139 & 118.62 & 16487.50 & 6757.50 & $0.020^{*}$ \\
& Male & 117 & 140.24 & 16408.50 & & \\
\hline
\end{tabular}

As seen in Table 7, there was no significant difference in Turkish learners' writing anxiety scale scores by gender $(\mathrm{U}=8124.50, \mathrm{p}>0.05)$. However, a significant difference was found in Turkish learners' writing self-efficacy scale scores by gender $(U=6757.50, p<0.05)$, which favored male students.

\section{Conclusion, Discussion, and Recommendations}

The study results indicated a significant positive relationship between writing anxiety and writing self-efficacy of students who learned Turkish as a foreign language. This finding overlapped with several similar findings in the literature. In this sense, Bandura (2010) stated that low self-efficacy in any activity led to one's feeling inadequacy for completing that activity, and thus those people experience more anxiety than those with high self-efficacy. Similarly, Senemoğlu (2011) pointed out low self-efficacy as one of the primary sources of anxiety. Arslan (2018) highlighted a moderate relationship between students' academic self-efficacy and writing anxiety total scores.

There was no significant difference between the Turkish learners' scores from the writing anxiety scale and their language level. In their studies, İşeri and Ünal (2016), Öztürk (2012) and Özsoy (2015) found no meaningful difference between writing anxiety and grade level. Similarly, Akbulut (2016) concluded that the writing anxiety of students learning Turkish as a foreign language did not differ significantly by language level.

There was no significant difference in the Turkish learners' scores from the writing anxiety scale by gender. Nevertheless, there was a significant difference in the Turkish learners' scores from the writing self-efficacy scale by gender. This difference favored male students. In their studies, Maden et al. (2015) and Akbulut (2016) concluded that the writing anxiety of students learning Turkish as a foreign language did not vary by gender. Tiryaki (2011) revealed that the writing anxiety of university students did not differ by gender.

Similarly, in their study Arıcı and Dölek (2020) determined that the perceived level of writing self-efficacy did not significantly differ by gender. Similarly, Pajares and Valiante (2006) found that male and female students had similar perceptions of writing self-efficacy. However, there are various findings regarding whether gender is a significant variable in writing self-efficacy in the literature. Gecas (1989) stated that the effect of gender on self-efficacy mainly differed due to age and family life and lost its effect on self-efficacy with the increasing age. Individual factors such as past experiences, family structure, and socialization were also determinants in the effect of gender on self-efficacy (cited in Arıcı \& Dölek, 2020, p. 1212).

Özdemir and Erdem (2011) found that Turkish teacher candidates' writing habits were high in the sub-dimensions of obeying the spelling and punctuation rules and writing competence. They also determined that the habit of using writing as a communication tool and as a literary genre was very low in the sub-dimensions of using writing tracks. This finding proved that people became very anxious when they thought they would make spelling and punctuation mistakes in writing. Therefore, it can be inferred that students' acceptance of using writing to communicate and express themselves plays an essential role in decreasing their writing anxiety.

It is well-known that students have high writing self-efficacy when they write about a topic of their interest (Hidi et al., 2002). Successful experiences reinforce and improve self-efficacy perception. Thus, students should start writing on the topics they can handle and are interested in (Melanlığlu \& Demir Atalay, 2016).

A person becomes more active, effective, and successful as long as s/he can cope with anxiety. As writing is the most critical tool for continuous self-expression, it becomes vital to eliminate any negative factors that affect writing (Arslan, 2018). According to Barış and Şen (2019), environmental anxiety was the primary source of writing anxiety among those who learned Turkish as a foreign language, showing that those students were influenced by their friends/peers, and teacher attitudes are critical for them.

It is vital to minimize and control writing anxiety. Therefore, the factors that affect writing anxiety should be determined (Karateke Bayat, 2018). Young (1991) emphasized "in-class practices" as the primary factors that caused anxiety. Karakaya and Ülper (2011) stated that "the more in-class and out-of-class writing activities/assignments teachers gave, the less writing anxiety students had." Similarly, Ürün Karahan (2017) indicated that students had more writing habits and perceived writing as a communication tool, the less writing 
anxiety they had. In other words, individuals with writing habits and who accept writing as communication have less writing anxiety. İşcan $(2015$, p. 149) suggested that teachers frequently did writing activities without time limitation to eliminate or minimize students' writing anxiety; they could reinforce and encourage students' self-confidence in writing and choosing collaborative learning strategies in writing classes.

\section{References}

Akbulut, S. (2016). Writing attitudes and concerns of Turkish learners as a foreign language. Unpublished master's thesis. Pamukkale University, Institute of Educational Sciences, Denizli.

Arıc1, M. A., \& Dölek, O. (2020). The relationship between secondary school students' writing self-efficacy perception and writing performance. Journal of Mother Tongue Education, 8(4), 1204-1217.

Arslan, A. (2018). An investigation of secondary school students' writing anxiety and academic self-efficacy beliefs. Abant İzet Baysal University Journal of Education Faculty, 18(3), 1286-1312.

Aşılloğlu, B., \& Özkan, E. (2013). An investigation of secondary school students' writing anxiety: The case of Diyarbakır. The Journal of Academic Social Studies, 6(6), 83-111. https://doi.org/10.9761/JASSS1527

Bandura, A. (1982). The assessment and predictive generality of self-percepts of efficacy. Journal of Behavior Therapy and Experimental Psychiatry, 13(3), 195-199. https://doi.org/10.1016/0005-7916(82)90004-0

Bandura, A. (2010). Self-efficacy. The Corsini Encyclopedia of Psychology, 1-3. https://doi.org/10.1002/9780470479216.corpsy0836

Barış, H., \& Şen, Ü. (2019). Writing anxiety in teaching Turkish as a foreign language. Aydın Tömer Journal of Language, 4(2), 73-99.

Boylu, E. (2014). Writing problems of Iranian students learning Turkish as a foreign language. Journal of World of Turks, 6(2), 335-349.

Büyükikiz, K. (2012). Developing writing skills self-efficacy scale for foreigners learning Turkish as a second language: Validity and reliability study. Mustafa Kemal University Journal of Social Sciences Institute, 9(18), 69-80.

Büyüköztürk, Ş., Kılıç-Çakmak, E., Akgün, E. Ö., Karadeniz, Ş., \& Demirel, F. (2014). Scientific research methods. Ankara: Pegem Academy Publishing.

Demir, S. (2016). Writing anxiety levels and reasons of Turkish teacher candidates: A mixed-method approach. Unpublished master's thesis. Yüzüncü Yıl University. The Institute of Educational Sciences, Van.

Demir, T. (2013). The relationship between primary school students' creative writing skills and writing self-efficacy perceptions. International Journal of Turkish Literature, Culture, and Education (TEKE), 2(1), $84-114$.

Demir, T. (2014). Validity and reliability study of the Turkish version of the writing self-efficacy scale. E-Kafkas Journal of Educational Research, 1(2).

Ehrman, M. E., \& Oxford, R. L. (1995). Cognition plus: Correlates of language learning success. Modern Language Journal, 79, 67-89. https://doi.org/10.1111/j.1540-4781.1995.tb05417.x

Fraenkel, J. R., \& Wallen, N. E. (2009). How to design and evaluate research in education (7th ed.). New York: McGraw-Hill.

Gardner, R. C. (1985). Social psychology and second language learning: The role of attitudes and motivation. London: Edward Arnold.

Hidi, S., Berndorff, D., \& Ainley, M. (2002). Children's argument writing, interest, and self-efficacy: An intervention study. Learning and Instruction, 12. https://doi.org/10.1016/S0959-4752(01)00009-3

Hidi, S., \& Boscolo, P. (2008). Motivation and writing. In C. A. MacArthur, S. Graham \& J. FitzGerald (Eds.), Handbook of writing research (pp. 144-157). New York, NY: Guilford Press.

İşcan, A. (2015). A study on writing anxiety in teaching Turkish as a foreign language (The Case of Ürdün University). Journal of Language and Literature Education, 14.

İşeri, K., \& Ünal, E. (2012). Turkish teacher candidates’ writing anxiety. Mersin University Journal of Education Faculty, 8(2), 67-76.

Karakaya, İ., \& Ülper, H. (2011). The Development and review of the writing anxiety scale. Educational Sciences in Theory and Practice, 11(2), 691-707. 
Karakuş, T. E., \& Taşkın, Y. (2018). Developing the writing anxiety scale for secondary school students: A validity and reliability study. International Journal of Turkish Literature Culture Education, 7(2), 1172-1189. https://doi.org/10.7884/teke.4169

Karasar, N. (2009). Scientific research method. Ankara: Nobel Publishing Distributor.

Karateke, B. B. (2018). The effect of peer assessment in teaching Turkish as a foreign language on students' writing anxiety. Unpublished master's thesis. Nevşehir Hacı Bektaş Veli University, Nevşehir.

Kurt, T. (2012). Teachers' self-efficacy and collective efficacy perceptions. Turkish Journal of Educational Sciences, 10(2), 195-227.

MacIntyre, P. D., Noels, K. A., \& Clement, R. (1997). Biases in self-ratings of second language proficiency: The role of language anxiety. Language Learning, 47, 265-287. https://doi.org/10.1111/0023-8333.81997008

Maden, S., Dincel, Ö., \& Maden, A. (2015). Writing anxiety of those learning Turkish as a foreign language. International Journal of Turkish Literature, Culture, and Education (TEKE), 4(2), 748-769. https://doi.org/10.7884/teke.488

Matoti, S., \& Shumba, A. (2011). Assessing the writing efficacy of post-graduate students at a university of technology in South Africa. Journal of Social Sciences: Interdisciplinary Reflection of Contemporary Society, 29, 109-118. https://doi.org/10.1080/09718923.2011.11892961

Melanlığlu, D., \& Atalay, T. D. (2016). The effect of creative writing practices on the writing self-efficacy of those learning Turkish as a foreign language. Turkish Journal of Social Research, 20(3), 697-721.

Özbay, M. (2011). Writing education. Ankara: Pegem A Publishing.

Özdemir, N. H., \& Erdem, İ. (2011). An analysis of Turkish teacher candidates' writing habits. Usak University Journal of Social Sciences, 4(2), 101-125.

Özonat, Z. (2015). Eighth-grade students' writing self-efficacy perceptions. Erzincan University Journal of Social Sciences Institute, 2, 207-220.

Özsoy, Y. (2015). Writing anxiety of special talented (gifted) secondary school students. Unpublished Master's Thesis. Sakarya University Institute of Educational Sciences, Sakarya.

Öztürk, B. K. (2012). Secondary school students' writing anxiety. Çukurova University Journal of Social Sciences Institute, 21(2), 59-72.

Pajares, F., \& Valiante, G. (2006). Self-efficacy beliefs and motivation in writing development. In C. MacArthur, S. Graham \& J. Fitzgerald (Eds.), Handbook of writing research (pp. 158-170). New York: Guilford Press.

Pamuk, Y., Hamurcu, H., \& Armağan, B. (2014). Classroom teacher candidates' state and trait anxiety levels (Izmir-Buca example). Bartın University Journal of Education Faculty, 3(2), 293-316. https://doi.org/10.14686/BUEFAD.201428183

Petzel, T. P., \& Wenzel, M. U. (1993). Development and initial evaluation of a measure of writing anxiety. Paper presented at the American Psychological Association Convention, Toronto.

Sakız, G. (2013). Keyword in success: Self-efficacy. Journal of Uludağ University Education Faculty, 26(1), 185-209.

Şen, U., \& Boylu, E. (2017). Development of a writing anxiety scale for those who learn Turkish as a foreign language. International Journal of Turkish Literature Culture Education, 6(2), 1122-1132. https://doi.org/10.7884/teke.3886

Senemoğlu, N. (2011). Development learning and teaching. Ankara: Pegem Academy.

Sevim, O., \& Özdemir Erem, N. H. (2013). Effects of creative drama on students' writing anxiety. Adlyaman University Journal of Social Sciences Institute, 11, 975-992. https://doi.org/10.14520/adyusbd.413

Tayşi, E. K. (2018). Development of the anxiety scale of writing in Turkish as a foreign language: A validity and reliability study. Turkish Journal of Social Research, 22(4), 1033-1050.

Thompson, M. O. (1980). Classroom techniques for reducing writing anxiety: A study of several cases. Paper presented at the annual conference on College Composition and Communication, Washington, D.C.

Tiryaki, E. N. (2011). University students' argumentative writing skills, writing anxiety and critical thinking skills. Unpublished master's thesis. Mustafa Kemal University Institute of Social Sciences, Hatay.

Ürün Karahan, B. (2017). The relationship between writing anxiety and writing habits of Turkish teacher 
candidates. Itobiad: Journal of the Human \& Social Science Researches, 6(5).

Yilmaz Soylu, M., \& Akkoyunlu, B. (2019). The adaptation study of the writing self-efficacy scale to Turkish. Kastamonu Journal of Education, 27(5), 2233-2242. https://doi.org/10.24106/kefdergi.3423

Young, D. J. (1991). Creating a low-anxiety classroom environment: What does the language anxiety research suggest? Modern Language Journal, 75(4), 426-437. https://doi.org/10.1111/j.1540-4781.1991.tb05378.x

\section{Copyrights}

Copyright for this article is retained by the author, with first publication rights granted to the journal.

This is an open-access article distributed under the terms and conditions of the Creative Commons Attribution license (http://creativecommons.org/licenses/by/4.0/). 